\title{
Diontos
}

Revista de Comunicación Digital

\section{Canales de vídeo de doblaje paródico en YouTube en España. Los casos de Loulogio, Desahogada, Korah, Keunam y HDub}

\section{Parodic dubbing channels on YouTube in Spain. The cases of Loulogio, Desahogada, Korah, Keunam and HDub}

\section{Javier Trabadela-Robles}

jtrarob@unex.es

Universidad de Extremadura
(iD) Diego-Jesús Corral-Motino diego.corral@canalextremadura.es Canal Extremadura Televisión

\section{RESUMEN}

Las posibilidades creativas que ofrecen los medios sociales son ilimitadas. Entre ellas está el humor en clave de parodia. Los doblajes paródicos en YouTube han adquirido una relevancia considerable durante la última década, tanto a nivel internacional como en España. El objetivo de este trabajo es estudiar las creaciones paródicas de autores hechas en este medio social desde España. Para ello, se utiliza una metodología de estudio de caso múltiple, para lo que se efectúa una selección de creadores, de cuyos canales se realiza un análisis de contenido. La muestra la componen los canales de: Loulogio, Desahogada, Korah, Keunam y HDub, quienes han revolucionado el panorama humorístico creando iconos únicos e irrepetibles y logrando grandes cantidades de seguidores y visitas. Entre los resultados destaca que los autores plasman toda su creatividad usando el doblaje de un modo cómico, espontáneo, marcado por la autenticidad y sus estilos claros e inconfundibles. También que en este tipo de vídeos predominan las referencias locales, aunque intentan ser lo más globales posibles para mantener su gran audiencia. Hay diferencias como el distinto nivel de profesionalidad de los autores (en función de sus perfiles reales) y de los primeros vídeos a los actuales, de mucha mayor calidad técnica. En definitiva, cinco comunicadores originales, creativos y con un sentido del humor único.
PALABRAS CLAVE parodia humor youtuber internet creatividad

Recibido: 07/03/2020

Aceptado: 22/06/2020

Edita: Lorena Cano-Orón

Cómo citar este artículo:

Trabadela-Robles, J. y Corral-Motino, D. J. (2021). Canales de vídeo de doblaje paródico en YouTube en España. Los casos de Loulogio, Desahogada, Korah, Keunam y HDub. Dígitos. Revista de Comunicación Digital, 7: 141-165. DOI: 10.7203/rd.v1i7.187 


\begin{abstract}
The creative possibilities offered by social media are limitless. Among them is humour in the form of parody. Parodic dubbing on YouTube has acquired considerable relevance over the last decade, both internationally and in Spain. The aim of this paper is to study the parodic creations of authors made in this social medium from Spain. To this end, a multiple case study methodology is used, for which a selection of creators has been made, and a content analysis is carried out on their channels. The sample is made up of: Loulogio, Desahogada, Korah, Keunam and HDub. They have revolutionized the humorous scene by creating unique and unrepeatable icons and achieving large numbers of followers and views. Among the results, it stands out that the authors express all their creativity using dubbing in a comical, spontaneous way, marked by authenticity and their clear and unmistakable styles. Also, that in this type of videos local references predominate, although they try to be as global as possible to maintain their large audience. There are differences such as the level of professionalism of the authors (according to their real profiles) and from the first videos to the most recent ones, of much higher technical quality. In essence, five original creative communicators with a unique sense of humour.
\end{abstract}

\section{KEYWORDS}

parody

humour

fandub

internet

youtuber

\title{
1. Introducción
}

El humor resulta imprescindible en el día a día del ser humano. Ramos (2007: 221) destaca que el humor es uno de los recursos más importantes a la hora de realizar campañas de comunicación viral en Internet, puesto que muchos usuarios destinan gran parte de su tiempo al entretenimiento, con contenidos humorísticos que les hagan desconectar de la tensión del trabajo diario, al mismo tiempo que otra parte de los usuarios utiliza dichos contenidos para fortalecer las relaciones sociales, al fomentar y compartir estos recursos humorísticos entre estos círculos sociales.

En ocasiones el humor y la diversión vienen propiciados por la exageración, el humor absurdo o la parodia. La autora señala: "La comunicación viral se presenta como una reformulación del tradicional 'bocaoreja' impulsado por la utilización de las nuevas tecnologías. Esta nueva práctica [...] pretende imitar el comportamiento natural de las relaciones sociales" (ibídem: 224).

Y este humor viral no es exclusivo de espacios de entretenimiento, sino que es posible incluso en canales y medios tradicionales y en géneros tan 'serios' como los informativos, como ocurriera con el caso del profesor Kelly, cuando la BBC le entrevista en directo por videoconferencia y se cuelan sus hijos apareciendo en pantalla, lo que propició que el vídeo se hiciera rápidamente viral por lo divertido de la situación (Israel y Pomares, 2019). 
En este trabajo se analizan algunos de los canales más conocidos de doblaje paródico en YouTube en España. La investigación se justifica por la ausencia de trabajos previos sobre este objeto de estudio tan específico y peculiar.

\subsection{Objetivos}

El objetivo general de esta investigación y principal aportación es analizar algunos de los canales de doblaje más representativos en YouTube, en España, que tanto éxito han tenido en los últimos años, especialmente entre los jóvenes.

Para alcanzar ese objetivo general, se plantean los siguientes objetivos específicos:

1) En una primera fase, explorar la plataforma YouTube buscando los principales canales de doblaje en España y realizar una selección de los mismos, para poder delimitar el objeto de estudio.

2) Realizar un análisis de contenido de los canales seleccionados, para poder definir cada canal y extraer elementos característicos de cada autor.

3) A partir de los resultados del análisis de contenido de los canales, intentar establecer los elementos comunes y diferenciadores de los mismos, de modo que se puedan extraer las características definitorias de este tipo de doblajes paródicos.

\subsection{Preguntas de investigación}

Conociendo la existencia de estos canales de doblaje paródico en YouTube, surgen algunas preguntas iniciales de investigación: ¿habrá unos elementos comunes en relación a los temas y al uso de los recursos audiovisuales en este tipo de canales? ¿Habrá también diferencias que los hagan suficientemente autónomos, de modo que cada creador tenga su estilo propio y pueda tener su público específico? ¿Cuál es el perfil de los autores? ¿Tendrán una formación previa o relación profesional con los medios? ¿Qué características podrían ser la causa del éxito de estos canales?

\section{Marco teórico}

El humor ha sido estudiado en numerosas ocasiones desde diversas perspectivas, especialmente desde los estudios literarios y lingüísticos. La parodia también ha sido muy estudiada desde la literatura y la lingüística, hasta el punto de existir un problema teórico en torno a su definición, según algunos autores como Ivanov (2006).

Desde la Comunicación, es destacable el monográfico sobre el humor que publicó en 2002 la revista Cuadernos de Información y Comunicación, coordinado por Valbuena y Aladro. En él se incluyen numerosos estudios de autores clásicos y también más recientes, en los que se trata el humor desde diversos puntos de vista como, por ejemplo, el propio concepto de humor o humorismo (Casares, 1961).

Hay numerosos estudios sobre el humor en la televisión en general (Méndez, 2003; Pérez, 2007; Aguilera, 2019), también sobre la comedia televisiva y sus características (Gordillo, 2015; Gómez, 2020), pero no hay tantos sobre la imitación o la parodia en el audiovisual (Hutcheon, 2000, Ríos, 2011; Gómez, 2015; Fernández, 2018; Gascón, 2019).

En algunos de los casos que se trata la parodia en el audiovisual, ya sea en televisión 
o en YouTube, se hace desde un enfoque relacionado con la política o de identidad cultural. Por ejemplo, la parodia informativa como frivolización del discurso político (Méndez, 2014); el estudio de caso sobre la identidad nacional generada a través de una serie uruguaya en YouTube (Andacht, 2017); o la imagen de los inmigrantes llegando a lo paródico en algunas sitcoms españolas (Abad y Fernández, 2018).

Casi todos los estudios sobre el doblaje en general se centran en la parte lingüística y de traducción. Apenas se encuentra algunas publicaciones sobre el doblaje desde el punto de vista audiovisual, casi siempre relacionadas con el trabajo del actor de doblaje y de carácter divulgativo (Costa, 2013).

En relación a los vídeos online basados en el doblaje se podría mencionar el fandub o doblaje hecho por aficionados. Sobre este particular sí hay algunos estudios, como el de Jaramillo y Suárez (2013), que se centra en América Latina o el de Maranhão et al. (2019), sobre estas creaciones en Brasil, pero hay que recordar que este fenómeno no suele referirse a un doblaje paródico ni humorístico, sino a doblajes extraoficiales producidos por fans distintos de los originales.

Un aspecto relevante del objeto de estudio es que hay que considerar que los doblajes paródicos se basan en la creación de una obra derivada de un original previo. Esto quiere decir que los autores se basan en material ajeno, sobre cuyo uso no suelen pedir permiso con antelación, lo que en muchas ocasiones provoca problemas de derechos y la eliminación de vídeos de las plataformas donde se alojan. Estos casos de la obra derivada de las parodias también han sido estudiados desde el punto de vista legal (Tobar, 2014; Schneider, 2016).

El trabajo que se ha encontrado que más se aproxima al objeto de estudio es el de Boxman-Shabtai (2019). En esta investigación se trata la parodia en YouTube, aunque se centra exclusivamente en la parodia tanto de vídeo como de audio de vídeos musicales (por tanto, no son casos sólo de doblaje). Aunque no coincida exactamente el objeto de análisis, resulta de gran interés por las conclusiones a las que llega la autora tras entrevistar a 22 creadores.

Tal y como afirman Nitrihual y Galera (2011: 99), "el discurso humorístico aparece ante nuestros ojos como un conjunto más o menos elaborado de comunicaciones mediatizadas y en esa medida debe establecerse su correlación con el medio en el que se difunde". Por tanto, resulta oportuno analizar brevemente el contexto online, la plataforma YouTube y el fenómeno youtuber.

Desde sus comienzos en 2005, YouTube ocupa un lugar privilegiado en la vida diaria de millones de personas a nivel mundial y ha supuesto un punto de inflexión en el consumo y en la creación de los contenidos audiovisuales. A pesar de que existan otras plataformas de vídeo en la red, como Dailymotion o Vimeo, YouTube es sin duda la más conocida y explotada y donde muchos creadores suben sus contenidos para su difusión. Es, junto con Facebook, Twitter, Pinterest e Instagram, la red social más usada en el mundo (Statcounter GlobalStats, 2020), formando parte imprescindible del plan de medios sociales de cualquier empresa (y de los propios youtubers) y, sobre todo, encontrándose bien posicionada para la mayor parte de la población.

Una de las múltiples ventajas de YouTube es la enorme libertad de la que disponen los creadores para subir y promover sus propios contenidos, sin exigencias impuestas 
por productoras, como pasaba en televisión, y sin necesitar grandes medios técnicos (Pérez y Gómez, 2010). Una persona, desde su hogar, puede realizar cualquier tipo de contenido, tan sólo recurriendo a la creatividad y la originalidad, a lo que responde el concepto de "DIY" ("Do It Yourself": "Hazlo tú mismo"; Sádaba y Rendueles, 2016: 109). Además, hay que sumar la recompensa de rentabilidad económica que les puede suponer a los creadores (Jorge, Marôpo y Nunes, 2018), si bien parece que YouTube cada vez se pudiera parecer más a los medios convencionales (Márquez y Ardèvol, 2018).

El éxito o fracaso de los vídeos puede depender de muchos factores, como la calidad final (tanto técnica como argumental), innovación, afinidad de los espectadores, o si trata algún tema candente o potencialmente viral (en la que influye mucho la comunidad existente en torno al youtuber; Feroz y Vong, 2014).

En YouTube no hay tantas exigencias técnicas como en los medios convencionales: el creador juega de forma independiente y lo que cuenta y cómo lo cuenta (la originalidad, la elocuencia y la narrativa) suele prevalecer por encima de las características técnicas (aun así, esto depende de cada caso; no hay garantía del éxito).

YouTube también ofrece muchas posibilidades al espectador, actuando como una especie de "repositorio" de contenido audiovisual (Galindo y Nó, 2010: 154). Pero su importancia no se debe sólo a ser una plataforma que da soporte a infinidad de vídeos, sino que destaca también por ser una red social, donde los usuarios espectadores tienen gran protagonismo en cuanto a la posibilidad de interactuar con el creador mediante comentarios, likes y la propia suscripción para estar al tanto de cada vez que un canal se actualice con nuevo contenido. Además, gracias a ese feedback, el espectador consigue influir en los contenidos de los creadores estableciendo constantemente interacciones sobre lo que gusta y lo que no. De este modo, los autores pueden, por ejemplo, hacer una u otra edición final de un vídeo en función de la información exacta que les llega a través de herramientas como Google Analytics, pudiendo interactuar con los diversos comentarios y conociendo el nivel de afinidad gracias a los likes y visitas totales, además de saber la procedencia geográfica de los visitantes, todo lo cual influye en el conocimiento que se dispone sobre qué tipos de contenidos funcionan y cuáles no.

Por otro lado, para subir contenidos en YouTube no es necesario estar formado en el mundo audiovisual ni tener ningún tipo de especificación, lo cual siempre ha sido imprescindible para acceder a determinados medios del ámbito profesional de la producción audiovisual.

En definitiva, se ha producido una democratización del vídeo online, acabando con el monopolio de las grandes productoras audiovisuales (Sádaba y Rendueles, 2016: 109). Esto ha generado polémica, ya que alguien no profesional, desde su casa, puede tener más audiencia en un solo vídeo de bajo coste que un programa de televisión en directo de gran presupuesto. Esto va en la misma línea de la "desintermediación", expuesta por Orihuela (2002) entre sus "nuevos paradigmas de la comunicación", consistente en la eliminación de los filtros y la mediación de los profesionales de los medios.

Por tanto, se ha pasado del audiovisual hecho por profesionales en unas estructuras de producción muy definidas al eslogan de la plataforma YouTube "Broadcast Yourself" ("difúndelo tú mismo"), donde no hay limitaciones creativas (salvo las legales ya apuntadas) y cualquier usuario puede registrarse y comenzar a subir los contenidos 
audiovisuales que considere oportunos (Pérez y Gómez, 2010). Además, con la gran baza del hipervínculo, un concepto que sólo existe en Internet, y que propicia que un usuario pueda saltar de una información a otra (o de un vídeo a otro) según determinados conceptos relacionados, acordes al interés de éste. A fin de cuentas, no deja de ser algo parecido al zapping de la era televisiva (Murolo, 2010).

En relación al tipo de contenido existente en la plataforma, como se ha mencionado, se puede encontrar de todo debido a su carácter global y a la diversidad, tanto en creadores, como en consumidores de los vídeos. Sin embargo, aunque pueda parecer paradójico, los usuarios también buscan lo local en YouTube, de modo que el producto ideal de la plataforma es aquel que Gallardo (2012: 5-6) define como "glocal". El autor explica que en España una gran cantidad de usuarios de YouTube se decanta por vídeos relacionados con la identidad cultural local, aun teniendo acceso a vídeos procedentes de todo el mundo. Esto es muy importante y algo a tener en cuenta en el presente trabajo, puesto que los creadores audiovisuales analizados utilizan la técnica de realizar doblajes locales, ya no sólo por el hecho de ser realizados en castellano, sino por hacer constantes bromas y alusiones a conceptos relativamente locales, sobre todo a nivel nacional, o incluso a nivel regional. Aunque esto pueda ser una limitación para otra gran parte de la población mundial (e incluso para el público latinoamericano), es una estrategia positiva para establecer el nicho de mercado y acaparar la atención de forma clara y potente en un público determinado.

Los creadores estudiados han sabido conectar con la audiencia, abordar temáticas que interesen y, sobre todo, ser honestos con el público y fieles a uno mismo, puesto que eso se transmite y el espectador lo detecta. Y, por supuesto, el éxito no hace que el trabajo desaparezca, sino que lo incrementa, puesto que "los youtubers, blogueros y blogueras trabajan mucho para sus medios y para sus seguidores, buscando nuevas ideas, realizando vídeos y posts y manteniéndose siempre atentos a lo que sus seguidores tienen que decirles" (Gayá, 2015: 43).

Por último, resulta necesario explicar que los autores seleccionados y sus parodias tienen unos antecedentes muy claros: la parodia creada en la televisión convencional. Es el caso del programa "El informal" (Telecinco, 1998-2002), donde para rellenar tiempo decidieron utilizar material original de otros medios para ponerles voz con tono humorístico, lo cual causó un gran impacto en los espectadores. En 2017 tuvieron gran popularidad algunos doblajes enmarcados dentro del programa "Dani \& Flo", realizados sobre fragmentos del programa "Hombres, mujeres y viceversa", de tal modo que pareciera que sus protagonistas estuvieran conversando sobre trascendentes temas como filosofía, arquitectura o literatura (Olmos, 2017). Algunos de estos fragmentos llegaron a ser muy virales en Facebook.

De modo similar, los doblajes paródicos formaron parte de otros dos importantes programas (realizados por los mismos creadores, pero en diferentes canales), como es el caso de la sección 'Retrospecter' de "La hora chanante" (Paramount Comedy, 20022006) y 'Mundo viejuno' si hablamos de "Muchachada Nui" (La 2 de TVE, 2007-2010), en los cuales se realizaban algunos doblajes cómicos sobre películas de cine clásico.

En este contexto, influido por algunos de los programas televisivos citados anteriormente (y sumado a la capacidad creativa que ofrece una plataforma como YouTube), es donde toma impulso el formato de los doblajes paródicos en castellano. Algunos de 
los máximos exponentes en nuestro país en este género son: Loulogio, Desahogada, Korah, Keunam, y HDub. Todos ellos son de procedencia española, pero también tienen gran influencia en la comunidad youtuber de habla hispana (aunque algunos de ellos hagan alusiones más locales, entendibles dentro de nuestro país y más difícilmente exportables a países latinos).

\section{Diseño de la investigación y metodología}

Al no haber encontrado bibliografía previa específica sobre el objeto de estudio en la que poder localizar canales de interés en España, aunque para los autores eran conocidos algunos de los canales de doblaje paródico, lo primero que se hizo fue iniciar una fase exploratoria en YouTube de dichos canales. Tras esa fase, se procedió a una selección que configura la muestra objeto de estudio.

Teniendo presentes los objetivos marcados, se definieron los ítems de análisis configurando un modelo de análisis ad hoc y se aplicó teniendo como unidad de análisis el canal de cada autor seleccionado, no cada vídeo específico, si bien se analizaron algunos vídeos concretos en mayor profundidad que otros. Hay que recordar que el objetivo era extraer elementos definitorios de cada autor (no de determinados vídeos).

Por tanto, se diseña una investigación fundamentalmente cualitativa (aunque también se recogen algunos datos cuantitativos), basada en la metodología de estudio de caso múltiple (Yin, 2014), así como la de análisis de contenido (Krippendorf, 1990; Wimmer y Dominick, 1996).

El estudio se ha realizado desde noviembre de 2017 a febrero de 2020. Se han visualizado todos los vídeos y se han analizado en detalle los que cuentan con más visualizaciones y/o los que definen mejor cada canal.

\subsection{Objeto de estudio}

En la plataforma de vídeos YouTube se exploran muchas de las parodias en formato de vídeo que incluyen el doblaje (de voz) como elemento principal. En los últimos años, en España, ha habido diversos autores que han popularizado ampliamente dicho fenómeno.

La selección de los canales a analizar está basada en la veteranía y repercusión mediática que han tenido todos ellos a lo largo de los años, además de haber sido capaces de desarrollar un universo creativo propio. De este modo, se pone especial atención en los precursores de este tipo de creaciones y en aquellos que tienen un estilo propio y original.

Además de los canales seleccionados, descritos en el siguiente epígrafe, encontramos otros youtubers dedicados a doblajes paródicos con cierta popularidad, como: Xurxocarreno, Manzelot, Hermoti, Kibadubs o Trazzto. Sin embargo, se trata de canales menos originales y/o de menor trascendencia mediática. Por ejemplo, el canal de Xurxocarreno posee la considerable cifra de casi 400.000 suscriptores, pero su contenido se encuentra enormemente influido por el de El Canal de Korah. Por su parte, Manzelot tiene 1.3 millones de seguidores, una cifra muy elevada, por la popularidad de algunos de los doblajes paródicos realizados durante los últimos años sobre la serie "Peppa Pig", así como otros relacionados con "Sonic", aparte de multitud de parodias de 
carácter musical. Pese a ello, no ha sido incluido en el análisis por no haber sido uno de los precursores del doblaje paródico, como sí lo fueron los seleccionados.

\subsection{Muestra de canales a analizar}

Los canales seleccionados son los de los autores: Loulogio, Desahogada, El canal de Korah, Keunam y HDub. Todos ellos son importantes canales de YouTube en español (Tabla 1), con difusión a nivel mundial entre la comunidad de habla hispana.

Tabla 1. Principales datos de los canales de YouTube seleccionados.

\begin{tabular}{|c|c|c|c|c|c|}
\hline $\begin{array}{l}\text { Nombre del } \\
\text { canal }\end{array}$ & $\begin{array}{l}\text { Fecha de } \\
\text { creación }\end{array}$ & Suscriptores & Vídeos & Visualizaciones & $\begin{array}{l}\text { Perfil en } \\
\text { YouTube }\end{array}$ \\
\hline Loulogio & $16 / 04 / 2006$ & 806.000 & 248 & 161.211 .642 & /loulogio \\
\hline Desahogada & $16 / 12 / 2008$ & 418.000 & 234 & 79.497 .847 & /Desahogada \\
\hline $\begin{array}{l}\text { El canal de } \\
\text { Korah }\end{array}$ & $13 / 07 / 2012$ & 1.850 .000 & 256 & 132.223 .190 & /ElcanaldeKorah \\
\hline Keunam & $26 / 02 / 2010$ & 419.000 & 209 & 101.599 .029 & /Keunam \\
\hline HDub & $25 / 06 / 2009$ & 488.000 & 29 & 50.822 .213 & / hctortm2 \\
\hline
\end{tabular}

Fuente: Datos extraídos de los propios canales en YouTube (actualizados a fecha de 27/02/2020).

A través de sus diferentes vídeos, los autores muestran su creatividad y se encargan de recopilar multitud de fragmentos de películas, series, $u$ otros elementos culturales audiovisuales (vídeos de televisión o de la red), para hacer sus versiones y obtener vídeos humorísticos. En multitud de ocasiones se convierten en virales, al ser compartidos de forma exponencial en redes sociales, llegando a millones de reproducciones y a colarse con muchos vídeos en el apartado de Tendencias de YouTube España.

\section{3. Ítems de análisis}

Se lleva a cabo un análisis de contenido sobre los distintos tipos de vídeos presentes, pero teniendo como unidad de análisis cada uno de los canales. Los elementos de análisis y las características a valorar en cada ítem se exponen en la Tabla 2.

Tabla 2. Modelo de análisis aplicado a cada canal

\begin{tabular}{|c|c|c|}
\hline $\mathbf{N}$ & Ítem de análisis & Características a valorar \\
\hline 1 & Nombre del canal & Nombre del canal y perfil en YouTube \\
\hline 2 & Fecha de creación & Fecha en la que se dan de alta en la plataforma \\
\hline 3 & $\mathrm{~N}^{\circ}$. de suscriptores & $\begin{array}{l}\text { En las estadísticas del canal se busca el dato de sus- } \\
\text { criptores }\end{array}$ \\
\hline 4 & №. de vídeos & Número de vídeos publicados \\
\hline 5 & Visualizaciones & Visualizaciones totales (estadísticas del canal) \\
\hline 6 & $\begin{array}{l}\text { Organización narrativa } \\
\text { y de producción }\end{array}$ & $\begin{array}{l}\text { Videos sueltos, listas de reproducción, periodicidad de } \\
\text { publicación, etc. }\end{array}$ \\
\hline
\end{tabular}




\begin{tabular}{|l|l|l|}
\hline N & Ítem de análisis & \multicolumn{2}{l|}{ Características a valorar } \\
\hline 7 & Temas tratados & $\begin{array}{l}\text { Líneas temáticas, temas recurrentes, referentes pa- } \\
\text { rodiados (películas, series, vídeos de Internet, pro- } \\
\text { gramas de TV, canciones, etc.), vídeos que hayan sido } \\
\text { grandes éxitos }\end{array}$ \\
\hline $\mathbf{8}$ & Estética y técnica & $\begin{array}{l}\text { Características audiovisuales (calidad de imagen y de } \\
\text { audio, efectos visuales), edición, calidad del doblaje, } \\
\text { etc. }\end{array}$ \\
\hline $\mathbf{9}$ & Perfil del autor & $\begin{array}{l}\text { Si tiene formación previa, profesional de los medios o } \\
\text { del doblaje, etc. }\end{array}$ \\
\hline 10 & Sinergias con otros & $\begin{array}{l}\text { Si colaboran unos con otros, si se hacen homenajes } \\
\text { unos a otros, etc. }\end{array}$ \\
\hline 11 & Otras características & $\begin{array}{l}\text { Por ejemplo, si han tenido problemas con cuestiones } \\
\text { de derechos, si han decidido no seguir creando vídeo } \\
\text { de este tipo, interacción de las creaciones publicadas } \\
\text { y en redes sociales, etc. }\end{array}$ \\
\hline
\end{tabular}

Fuente: Elaboración propia.

Los primeros 5 ítems de análisis son definitorios de cada canal, incluyendo elementos cuantitativos (se muestran en la Tabla 1). A partir del sexto ítem comienza el análisis cualitativo en el que se buscan las características propias de cada canal: su estructuración (ítem 6), su análisis desde una perspectiva de contenidos y temas (ítem 7) y, también, desde lo técnico y estético (ítem 8). Por último, se analiza al creador de los vídeos (9), su relación con otros autores (10) y se añade un campo (11), también abierto, donde se incluyen otras características que no tengan cabida en los ítems anteriores.

\section{Análisis de los canales, características comunes y diferencias entre ellos}

Una vez descrito el diseño de la investigación, se exponen a continuación las características generales de cada uno de los canales objeto de estudio: Loulogio, Desahogada, Korah, Keunam y HDub (Figura 1).
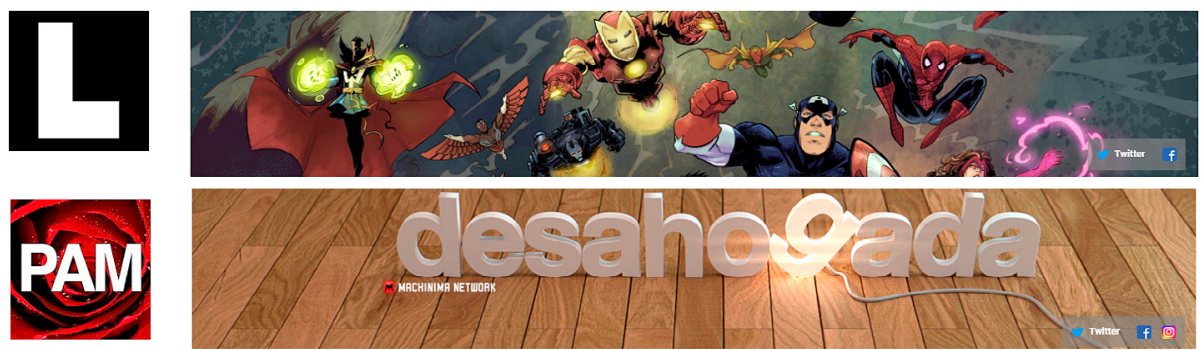

Figura 1. Iconos e imágenes de cabecera de los cinco creadores. De arriba a abajo:
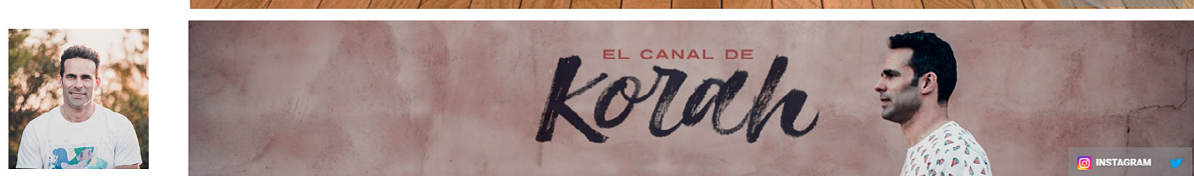

Loulogio, Desahogada, Korah, Keunam y HDub.
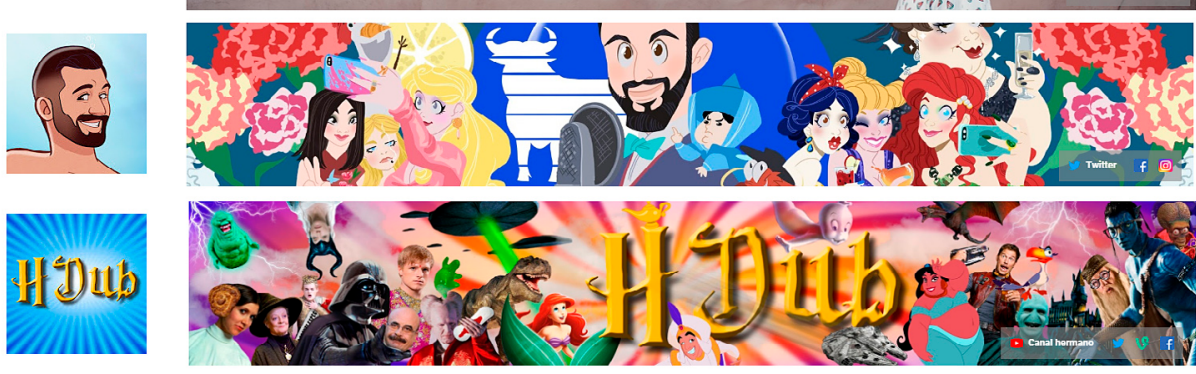

Fuente: elaboración propia a partir de imágenes tomadas de sus canales oficiales. 


\subsection{Loulogio}

Isaac Sánchez, conocido por su nombre artístico Loulogio, es un creador cuyo canal tiene más de 800.000 suscriptores y casi 250 vídeos $^{1}$. Comenzó compartiendo su primer vídeo en los inicios de YouTube, si bien, es en su segundo vídeo (julio de 2006) en el que realiza un doblaje de la versión española del famoso programa "Art Attack". A éste siguieron otros cuatro vídeos bajo los títulos de "Art Attax".

Estos vídeos reúnen ya sus características principales: se encuentran realizados de forma sencilla, tan solo obteniendo el fragmento de vídeo original perteneciente al programa (a veces incluso tomado en baja resolución) y doblado con unas frases paródicas sin relación directa con el contenido original, tan solo con la finalidad de hacer reír a base de humor absurdo. A veces Loulogio inserta imágenes originales grabadas por él, en medio del contenido del programa Art Attack, para que parezca que sus propios dibujos forman parte del programa, lo que incrementa la sensación de humor absurdo. Es un estilo particularmente gamberro, en el que encontramos una amplia variedad de expresiones coloquiales y malsonantes:

El mérito de Loulogio es haber convertido el estilo coloquial y humorístico que caracteriza a muchos jóvenes de su edad en un modo de expresión sólido, bien trabajado y exigente en cuanto a sus aspectos más profesionales. Sus vídeos pueden parecer, a primera vista, pequeños desastres descontrolados, pero su creatividad combina su espontaneidad natural con una elaboración muy pensada y trabajada (Jaraba, 2015: 56).

En lo que respecta la calidad técnica, ni el audio ni el vídeo adquieren una óptima calidad final (el audio suele saturarse). Y no está del todo relacionado con que hace ya mucho que se publicaron y entonces la calidad era menor, ni con que entonces el público se conformara con esa calidad, sino que es una estética buscada, que persigue conseguir una apariencia 'cutre'.

Este formato tan basto y descarado llegó a su culmen en 2010 con uno de sus vídeos más famosos y más icónicos de la historia de YouTube en España, al superar los diez millones de visitas. Se trata de "Labatamanta", nombre que le da título al vídeo en el que presenta un nuevo producto al que el propio Loulogio le puso el sobrenombre de "batamanta", un concepto que posteriormente se haría muy conocido en nuestro país. La clave del vídeo estaba en rediseñar por completo el concepto original, siendo un anuncio clásico de teletienda, pero añadiendo un doblaje que alude a cada una de las secuencias y les da un sentido diferente, insertando referencias culturales que enganchen al espectador. Esta tónica de doblajes de anuncios de teletienda también continúa en otros dos de sus vídeos más populares: "Pajilleitor plus" y "La chorrimanguera".

El autor, como todos, organiza sus creaciones en listas de reproducción, destacando la lista de "Art Attax", "Telemierda Entertainment" (doblajes de vídeos de teletienda), "Zapping" y "Doblajes de cine", dos listas en las que realiza doblajes televisivos y de algunas cintas cinematográficas, respectivamente, además de otras listas como "Sin perdón", donde incluye los diferentes vídeos de doblajes paródicos que ha realizado para canales como 'TopTrendingVideo' o 'Se Estrena'.

1. Todos los datos de suscriptores, número de vídeos y número de visitas han sido revisados por última vez el 20/02/2020. 
Otra característica del autor es que ha realizado colaboraciones externas a su canal. Por ejemplo, en el canal 'VistoLoVistoTV', realizó en 2012 un doblaje humorístico del polémico anuncio de la campaña de Loewe de ese año (tan criticado y ridiculizado).

En diciembre de 2017 regresó, después de seis meses de inactividad en este ámbito, con un doblaje titulado "Hablemos de hipotecas tipo fijo (Doblaje)", parodiando uno de los virales del momento.

Hay que aclarar que en la objetiva baja calidad de los doblajes de Loulogio influye que él no se dedica profesionalmente ni al doblaje ni al audiovisual. Trabaja en el formato humorístico presencial (monólogos y eventos similares) y en la creación de cómics.

\subsection{Desahogada}

La autora, quien prefiere no hacer público su nombre real, es otra de las figuras clave en los doblajes cómicos de YouTube en nuestro país, con más de 400.000 suscriptores en su canal Desahogada. Esta creadora, si bien dispone de canal propio desde finales de 2008, publicó su primer vídeo paródico en él en 2010, aunque antes de tener canal propio ya había realizado doblajes paródicos en el canal 'Forehead Comedy'. Alcanzó gran popularidad en 2011 y 2012 realizando doblajes parodiando a la videobloguera 'Spricket24', Lady Gaga o Glozell, entre otras. Esta última, precisamente, empezó a conocerse en España gracias a la popularidad de los vídeos de "Glozell gitana", donde Desahogada transformaba a esta youtuber procedente de Florida en una persona con acento cañí, sin realizar muchos cambios en la traducción literal, remarcando especialmente el acento a la hora de locutar, con lo que consiguió un gran éxito.

La autora, como sucede con el resto de creadores, realiza los vídeos sin petición previa de autorización a los autores de los vídeos originales, si bien suele citarles en la descripción de las versiones dobladas.

En comparación con Loulogio, los doblajes de Desahogada son más cuidados, puesto que elabora más la propia locución y mejora la estética de los vídeos. Además, suele añadir efectos de sonido, que acompañan el sentido cómico de la parodia. El conjunto puede recordar en ocasiones a locuciones de anuncios radiofónicos o televisivos, o a las voces de las teleoperadoras de compañías telefónicas. Esto ocurre en algunas de las bromas telefónicas realizadas, donde se juega con ese factor, a medio camino entre la seriedad y la comicidad sutil.

Al igual que en el caso anterior, en el canal incluye vídeos que no se corresponden necesariamente al concepto de doblaje, sino que son creaciones libres en los que su autora habla o trata de algún tema de forma ágil y rítmica (gracias al montaje). Utiliza una voz en off, siguiendo un estilo de locución similar a los doblajes (y con todo lo que ello implica, como imitar diferentes acentos, poner voces, etc.). Ejemplos de ello son vídeos en alusión a Twitter, Facebook, Navidades, bromas telefónicas, algún que otro gameplay (vídeo en el que se muestra un juego) y otras bromas recurrentes que forman parte de su estilo personal, donde abundan expresiones particulares e identificativas y donde, también, incluye algunos videoblogs en los que se relatan experiencias de viajes, todo ello manteniendo sus señas de humor y locuciones.

Del mismo modo que Loulogio tomaba un vídeo de "Art Attack", de la teletienda, o cualquier otro fragmento televisivo, y le modificaba el contexto completamente (creando una situación disparatadamente cómica), Desahogada lleva a cabo acciones parecidas, 
al apropiarse de vídeos de Lady Gaga o Beyonce y doblar sus voces como si estuvieran de compras o estableciendo ciertas conversaciones con fans. Ocasionalmente elige fragmentos de entrevistas, reconfigurándolas por completo bajo formatos cómicos, como los casos de "Saber Morir", el programa ficticio con un nombre parodia de "Saber Vivir" (1997-2009, La 1 de TVE), en el que la autora introduce rótulos de preguntas humorísticas que son contestadas con doblajes añadidos en las imágenes de personajes célebres como Miley Cyrus.

Entre sus aportaciones, destaca "Beyoncé comprando en el Mercadona" (subido en febrero de 2014, con más de millón y medio de visitas), tratándose de una parodia de lo que parece ser un acto promocional de la cantante, visitando un centro comercial que vendía su álbum estrenado entonces (el vídeo original se titula "Beyonce at Tewksbury Walmart"). Como suele ser habitual, Desahogada se toma sus propias licencias para modificar por completo las palabras pronunciadas por la cantante, así como las voces secundarias de otras personas (convertidas en "personajes") dentro del mismo vídeo, cambiando el tono de voz, añadiendo efectos de sonido, y contando con la voz adicional de Gabriel Sánchez, colaborador asiduo.

Otros vídeos de éxito han sido el "Anuncio 2012 Loewe - Parodia", que es la parodia de ese anuncio con más visualizaciones, con más de 1,3 millones; el protagonizado por Ariana Grande, a la que se le añade un doblaje de lo más choni (chabacano), como es el caso del vídeo titulado "Ariana Grande en la feria de Albacete" (2015), donde la cantante se encuentra en un Disneyland, y es parodiada como si se tratara de una entrevista en la que visita la feria de Albacete; así como el vídeo de “Oriana Grande - Mi rutina diaria", donde se parodian algunos vídeos cotidianos subidos originalmente por la artista, combinados con una entrevista de plano medio.

Tanto en estos vídeos como en otros de Desahogada, no faltan las canciones espontáneas de otros artistas como Camela o K-Narias, para acentuar humorísticamente el tono choni y cañí que pretende otorgarle a la parodia. Otro más reciente a destacar es "Cómo Rosalía reinventó el flamenco", de noviembre de 2019 y con casi 400.000 visualizaciones en 4 meses.

Los vídeos de Desahogada se caracterizan por un estilo a medio camino entre el formato televisivo (entrevistas, programas, reportajes...) y el comercial (la forma casi publicitaria de locutar determinadas frases). Tienen una estética relativamente elegante, sobre todo por la edición y la selección de vídeos, e incluyen contenidos cómicos diversos, imitando distintos tipos de voz y añadiendo un gran número de efectos y golpes de humor. Las protagonistas de sus vídeos suelen ser celebrities internacionales totalmente transformadas, caricaturizadas "a la española", con un tono agitanado o choni.

\subsection{El canal de Korah}

Carles Caparrós es el responsable de El canal de Korah, el que tiene más suscriptores (1.850.000) de los analizados y el que más rápido ha crecido, pues en primavera de 2015 apenas sobrepasaba los 100.000 suscriptores.

En este caso, el creador es actor profesional de doblaje y locutor que comenzó a ejercer como tal en el año 2006 y que, con la llegada de la crisis a los medios, empezó a publicar sus propios vídeos en YouTube. En 2012 publicó vídeos a medio camino entre gameplays y comentarios de su vida personal con diversas opiniones. Dentro de 
su propio canal, no sólo realizaba meros comentarios a partidas, sino que también comenzó a realizar doblajes del videojuego "Far Cry 3", bajo la serie de vídeos de "El último superviviente en Far Cry 3". Ponía voz a algunos de los personajes y al propio protagonista de la historia, como si se tratara de una voz en off. Fundamentalmente se trata de unos vídeos en los que, dentro del contexto del videojuego, se parodia al programa televisivo "El último superviviente" (Discovery Channel, 2006-2011), pero contando con un protagonista ficticio al que se le da el nombre de Venancio Grillo. La calidad de la locución hace que, si no fuera por el tono evidentemente humorístico, se asemeje a la locución real y profesional de un videojuego. De hecho, curiosamente, Caparrós (Korah) formó parte del doblaje original en castellano del videojuego "Far Cry 4". Esa misma técnica de doblajes fue empleada nuevamente en otros vídeos del canal, como los relativos al videojuego "GTA V".

El hecho de que Caparrós ya tuviera trabajo en el mundo del doblaje y la locución cuando comenzó con este tipo de creaciones demuestra que el salto a YouTube no implica una necesidad de búsqueda de ingresos de la plataforma, sino que más bien se trata de una forma de explotar con total libertad creativa determinados contenidos que no tienen nada que ver con la rutina laboral. Evidentemente, el aumento de popularidad y la ingente cantidad de reproducciones pueden acabar convirtiéndose en una fuente notable de ingresos.

Elío (2017) Ilega a comparar el estilo de humor y doblajes de Korah con el de Joaquín Reyes de "La hora chanante" y "Muchachada Nui", especialmente por la forma ocasional de modular la voz y por los guiños y referencias al mundo rural español.

Tras diversos vídeos semejantes a los descritos, en 2015 comienza a emitir la famosa serie "Doblando Virales", donde reutiliza gran cantidad de vídeos de YouTube para suprimirle el sonido original y crear ingeniosos doblajes humorísticos. Se aprovecha de las diferentes situaciones que tienen lugar, poniendo voz a los protagonistas y añadiendo ocasionalmente voces en off, donde a veces hace un ejercicio cercano a la locución deportiva, todo ello acentuado con diversidad de efectos de sonido. En su mayoría se trata de vídeos cotidianos, caseros, pero potencialmente virales (tanto en el contenido original como en estos doblajes), un tipo de formato que recuerda a programas televisivos como "La cara divertida" (Antena 3, 1997-2000), donde precisamente también se exponía una recopilación de vídeos caseros humorísticos, con voces en off, efectos sonoros cómicos (aunque sin el factor doblaje en este caso) y risas enlatadas. El hecho de tomar esos vídeos de otros le ha llevado a tener en ocasiones reclamaciones legales de los autores o distribuidores originales.

Su canal incluye vídeos muy diversos, organizados en listas de reproducción. La más genérica es "Doblajes", donde se encuentran numerosas parodias, como las de celebridades como Leonardo DiCaprio, Quentin Tarantino, Hans Zimmer, John Williams, Mariano Rajoy, Kim Jong-un, Maldini, Miguel Arias Cañete, o Gordon Ramsey, entre otros. También incluye en esa lista algunos vídeos que se encuentran a modo de serie en otras listas, como los relativos a "El último superviviente" o los "Doblando Virales".

Otras de estas playlists están destinadas a videoblogs estándar, vídeos de preguntas y respuestas, vídeos patrocinados, opiniones, gameplays y un largo etcétera. En muchos de estos videoblogs explica el funcionamiento del mundo del doblaje desde dentro, además de reflejar sus opiniones y dar consejos relacionados con este mundillo, siempre 
desde una óptica profesional y rigurosa, tratando el tema con la mayor objetividad posible y mostrando ejemplos para facilitar la comprensión.

Korah también ha realizado algunas parodias de anuncios de la teletienda, debido al auge de ese tipo de vídeos a causa de Loulogio, analizado con anterioridad.

\subsection{Keunam}

Otro icónico youtuber que ha revolucionado Internet con sus doblajes paródicos ha sido Keunam (Manuel Bohajar), un murciano que inauguró su canal de YouTube en febrero de 2010, aunque no sería hasta varios años después cuando llegó a tener un éxito masivo en suscriptores y visualizaciones.

Salvo contadas excepciones, su canal está muy influido por los "Clásicos Disney". La mayoría de sus vídeos se corresponden con fragmentos de producciones de la famosa compañía de Walt Disney Pictures, a los que les cambia totalmente el tono y el vocabulario, creando situaciones surrealistas e hilarantes, siempre plagadas de canciones y ambientación musical, así como de sutiles alusiones a la situación económica, política y cultural de nuestro país.

Sus inicios fueron con parodias de "La Cenicienta", "Los 101 dálmatas" y "Blancanieves y los siete enanitos", para posteriormente adentrarse en otros universos, como el caso de "La Sirenita" o "Alicia en el país de las maravillas". Además, ha realizado parodias exclusivamente musicales de películas como "La Sirenita", "Aladdin", "Frozen" o "El jorobado de Notre Dame". Todo este fenómeno fue denominado por su creador como "Disney Ibérico" o "Disney a la española". De este modo crea prácticamente una entidad propia en la que "españoliza" a muchos de los personajes y situaciones originalmente de carácter más inocente, para reconvertirlas en parodias que contienen expresiones malsonantes y situaciones disparatadas e incluyendo numerosos guiños a expresiones murcianas (el origen del autor), como "copón", "pijo" o "acho", remarcando el acento.

Sus vídeos también suelen estar ordenados en listas de reproducción, como "La Cenicienta Ibérica" (2012-2013, con 12 capítulos), "Blancanieves Ibérica" (2013-2014, con ocho capítulos), "La Sirenita ibérica" (2013-2014, con 13 capítulos), "Alicia ibérica en el país de la histérica" (2014-2016, con 12 capítulos), "La venganza de la Paca - Cenicienta Ibérica 2" (2014-2015, con ocho capítulos), "La Durmiente ibérica" (2016-2017, con 17 capítulos) o "Mulana" (desde 2017, con ocho capítulos hasta finales de 2019). Estos vídeos "Disney" se caracterizan por la mezcla de las imágenes clásicas con sonidos que nada tienen que ver con los originales, siendo canciones y músicas típicas de España: desde Isabel Pantoja, Rocío Jurado o María del Monte a Peret, Cantores de Híspalis o Mónica Naranjo, Amistades Peligrosas o incluso algún concursante de Operación Triunfo.

La clave de estas parodias es que es el propio Keunam quien realiza casi siempre todas las voces, poniendo de manifiesto sus dotes de imitación y canto, destacando sin duda las imitaciones de personajes femeninos. No obstante, sería mejorable la escasa ambientación sonora que adquieren algunas secuencias, pues se echan en falta efectos de sonido ambientales, $y$ a veces algunas voces se encuentran retocadas digitalmente $y$ resultan artificiales. Todas estas historias, sumadas a la propia continuidad que las dotan de encanto y de una cierta intriga, por la expectación que genera un nuevo capítulo de una serie ya empezada, hacen que el público simpatice con estos contenidos y que se 
genere cierta identificación, al ser un producto local, mostrando el costumbrismo y lo rural a través de un humor algo vulgar, no siempre apto para todos los públicos.

Keunam creó para su canal algunas parodias mixtas con otros contenidos. Una de las más populares fue subida en 2015 bajo el nombre de "Murcianic", tratándose de un doblaje paródico de la película "Titanic", donde se mostraban algunas de las escenas clave de la película con una jerga murciana, de forma similar (pero aún más exagerada) a lo que hizo en sus parodias Disney. Esta parodia incluía un momento cómico de la famosa secuencia de la cena, en el que el personaje interpretado por Kathy Bates contaba un chiste. Exclusivamente ese momento fue utilizado hasta la saciedad en diferentes vídeos, contando multitud de chistes (uno en cada vídeo de 14 segundos), generando un nuevo icono imprescindible del canal. En la parodia este personaje se llamaba Pepa, por lo que esta categoría comenzó a llamarse "Los chistes de la Pepa", serie que incluye casi 50 vídeos.

Por otro lado, encontramos una lista con parodias mixtas, bajo el título de "Varieté e idas de olla", donde podemos ver diversos doblajes, algunos de ellos realizados al momento, de forma amena e improvisada (como el que realiza con HDub). En otros de estos vídeos, como los "Meme-Mix", nos encontramos también con otras voces colaboradoras, así como con montajes en los que no existe únicamente doblaje como tal, sino superposición de audios existentes sobre otras escenas diferentes.

Ha realizado otros doblajes paródicos de series de Netflix, como "Narcos", "Grace and Frankie" o "Sense8". También una gran cantidad de versiones musicales e incluso sketches grabados a imagen real parodiando los cuentos Disney desde una óptica al estilo de "Callejeros" (programa de televisión emitido por Cuatro), aunque esto último no tenga vinculación con los doblajes, pero sí influencia temática por sus vídeos de "Disney ibérico".

Por último, hay que hacer referencia al vídeo con más visualizaciones (casi 17 millones) de los analizados de todos los autores, la parodia "Despacito", en la que interpreta (junto a su habitual compañero Hermoti) el tema de Fonsi imitando estilo "espejo" (Fernández, 2018: 306) hasta 20 voces distintas de cantantes y personajes de ficción. Fue el vídeo no musical (es decir, excluyendo videoclips y canciones oficiales) más visto en España en 2017.
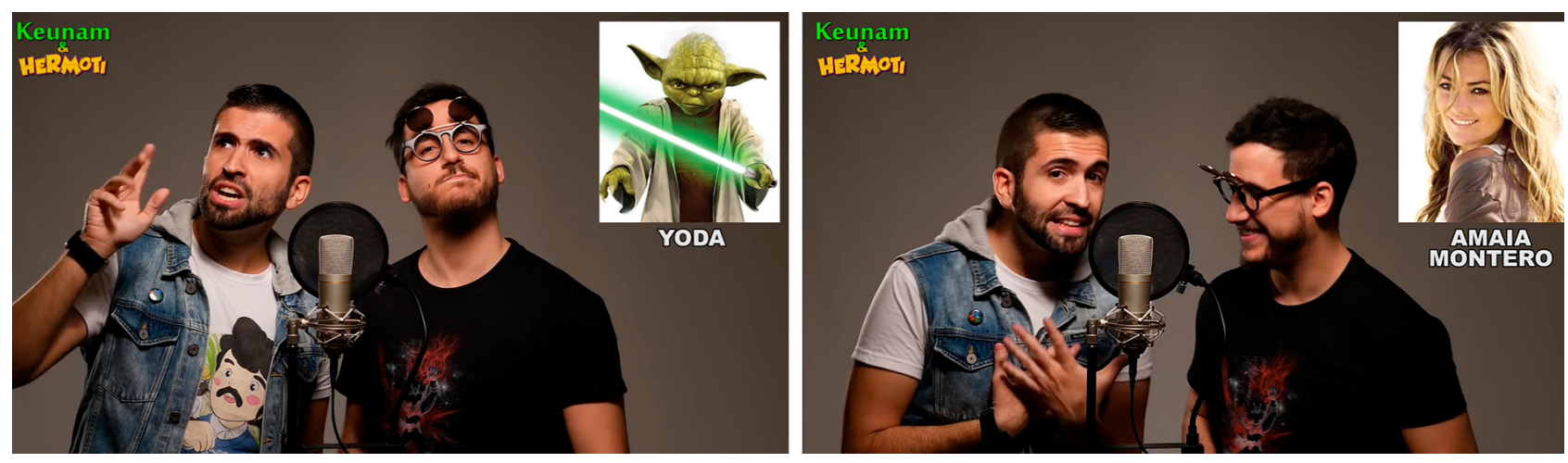

Figura 2. Capturas del vídeo parodia de Keunam y Hermoti de la canción "Despacito", de Luis Fonsi en el que incluyen hasta 20 voces distintas.

Fuente: https://www.youtube.com/watch?v=baxOTnMnOIU 
Tras la importante repercusión y difusión de sus vídeos, Manuel Bohajar ha llegado a trabajar en varios doblajes a nivel profesional y ha participado en concursos de talentos como "Got Talent" (Telecinco) en 2016 o "Tu cara no me suena todavía" (Antena 3) en 2017, demostrando su indudable calidad interpretativa.

\subsection{HDub}

Héctor García es uno de los youtubers con más auge en el terreno de los doblajes. En su canal principal, HDub (medio millón de suscriptores), encontramos vídeos donde el doblaje paródico adquiere una calidad excepcional. Los vídeos poseen una laboriosa postproducción y el doblaje en sí mismo llega a parecerse enormemente a las voces de los doblajes oficiales en castellano. Por ello, ha publicado "solamente" apenas unos treinta vídeos en este canal, debido a la gran cantidad de tiempo que requiere seleccionar momentos concretos de películas para su posterior parodia, crear el guion a partir de ahí, grabar las voces, montar el vídeo, añadir efectos visuales y sonoros en postproducción, etc. La clave de su éxito reside precisamente en la elaboración de un producto único que no realiza nadie más con ese grado de complejidad y paciencia.

Comenzó en 2010 doblando pequeños fragmentos de entrevistas extraídas de materiales adicionales de los DVD de Harry Potter, bastante sencillos, de humor absurdo que recuerda a Loulogio; de hecho, incluyen homenajes a su figura. Utiliza material externo para llevarlo a su terreno y transformar entrevistas convencionales en un formato de humor surrealista y absurdo en el que se produce un cruce de declaraciones por todos lados y donde nadie parece nunca saber muy bien qué está pasando. El autor emula todas las voces presentes y aprovecha cada una de las miradas de los personajes, cada silencio incómodo o cada gesto extraño, para convertirlo en una obra humorística única.

Tras esta primera incursión, fue definiendo su estilo propio en vídeos como: "Caspa ("Casper") - Recut Trailer", las parodias de "Juego de Tronos" ("Juego de Porros", "Juego de Troncos" y "Juego de Mocos" -todos ellos superando el millón de reproducciones-), "Tetanic (Titanic)", "El Señor de los Ajillos", "Pa qué juras chico (Jurassic Park trilogía)" o su gran éxito "Walt Disney Pichas".

Resulta característico de sus creaciones el insertar en sus vídeos fragmentos de otros youtubers como Elvisa Yomastercard o Salvador Raya, cantantes o personajes como Carmen de Mairena. Algo muy frecuente en HDub es la combinación de universos cinematográficos que puede llegar a mezclar en un mismo vídeo, pareciendo que todos estos universos confluyeran en uno mismo, a modo de crossover. Si algo queda claro tras visionar sus vídeos es el amor que tiene por el séptimo arte, ya que son innumerables los doblajes paródicos de películas de las últimas décadas, algunas de las cuales ya se han mencionado.

Una de las armas fuertes de Héctor García en YouTube es su canal secundario, Hache (más de 450.000 suscriptores), que complementa a la perfección su canal principal. De hecho, la actualización del canal secundario es mucho más frecuente, a pesar de que los vídeos sigan en su tónica habitual de poseer multitud de efectos visuales y complejo montaje. Además, es destacable que este canal sea incluso para un público más cinéfilo que el principal, puesto que se recurre a diferentes secciones de amplia información cinéfila y con relación con los doblajes profesionales.

La repercusión de Héctor García, creador y líder de HDub, hace que, a pesar de su relativo 
anonimato, pues no se expone públicamente tanto como Loulogio, Korah o Keunam, ha conseguido labrarse una carrera en el mundo del doblaje profesional, incluso antes de ser conocido en YouTube, gracias al hecho de ponerle voz a multitud de personajes. Algo similar sucede en lo relativo a algunos de sus colaboradores habituales, como Laura Monedero, Clara Schwarze, Alicia Valadés o Xenia Ramos, quienes son actrices profesionales de doblaje.

\subsection{Resumen de resultados y discusión}

En la Tabla 3 se muestra de forma esquemática un resumen de los resultados.

Tabla 3. Resumen de resultados (ítems 6-11). Fuente: elaboración propia

\begin{tabular}{|c|c|c|c|c|}
\hline Canal & Organización & $\begin{array}{l}\text { Temas trata- } \\
\text { dos }\end{array}$ & $\begin{array}{l}\text { Estética y téc- } \\
\text { nica }\end{array}$ & $\begin{array}{l}\text { Perfil, siner- } \\
\text { gias otros }\end{array}$ \\
\hline Loulogio & $\begin{array}{l}\text { Unos } 240 \text { vídeos } \\
\text { ordenados en } \\
\text { listas de repro- } \\
\text { ducción. } \\
\text { Publica periódica- } \\
\text { mente. }\end{array}$ & $\begin{array}{l}\text { Art Attax, teletien- } \\
\text { da (batamanta, } \\
\text { chorrimangue- } \\
\text { ra...), Zapping, } \\
\text { doblajes de cine, } \\
\text { etc. } \\
\text { Gamberro, basto } \\
\text { (expresiones co- } \\
\text { loquiales y malso- } \\
\text { nantes). }\end{array}$ & $\begin{array}{l}\text { Técnicamente } \\
\text { mejorable: vídeo } \\
\text { de baja calidad, } \\
\text { audio a veces } \\
\text { saturado. } \\
\text { Estética cutre } \\
\text { buscada. }\end{array}$ & $\begin{array}{l}\text { Precursor del } \\
\text { doblaje paródico } \\
\text { en YouTube en } \\
\text { España. No se de- } \\
\text { dica al doblaje, ni } \\
\text { a los medios (sino } \\
\text { a los monólogos } \\
\text { en vivo y a la crea- } \\
\text { ción de cómics). } \\
\text { Ha realizado } \\
\text { colaboraciones } \\
\text { externas (VistoLo- } \\
\text { VistoTV). }\end{array}$ \\
\hline Desahogada & $\begin{array}{l}\text { Algo más de } 230 \\
\text { vídeos. Publica de } \\
\text { forma irregular } \\
\text { con algunos paro- } \\
\text { nes de actividad. }\end{array}$ & $\begin{array}{l}\text { Glozell Gitana, } \\
\text { doblajes españoli- } \\
\text { zando a divas del } \\
\text { pop (Lady Gaga, } \\
\text { Rihanna, Ariana } \\
\text { Grande, Beyonce, } \\
\text { Miley Cyrus, etc.), } \\
\text { chistes, parodias } \\
\text { de anuncios y } \\
\text { programas de TV, } \\
\text { videoblogs con } \\
\text { voz en off. } \\
\text { Humor castizo } \\
\text { combinado con } \\
\text { iconografía pop } \\
\text { y frases únicas y } \\
\text { representativas } \\
\text { ideadas por ella } \\
\text { misma. }\end{array}$ & $\begin{array}{l}\text { Vídeos relativa- } \\
\text { mente sofistica- } \\
\text { dos, con locucio- } \\
\text { nes cercanas a un } \\
\text { estilo profesional } \\
\text { de actriz de do- } \\
\text { blaje o teleopera- } \\
\text { dora. } \\
\text { Uso de efectos } \\
\text { sonoros cómicos } \\
\text { y música para po- } \\
\text { tenciar el elemen- } \\
\text { to cañí. }\end{array}$ & $\begin{array}{l}\text { Quiere mantener- } \\
\text { se en el anonima- } \\
\text { to sin dar a cono- } \\
\text { cer su identidad } \\
\text { real. } \\
\text { Ha realizado } \\
\text { doblajes profe- } \\
\text { sionales ocasio- } \\
\text { nales, además de } \\
\text { colaboraciones } \\
\text { con marcas y con } \\
\text { otros youtubers. }\end{array}$ \\
\hline
\end{tabular}




\begin{tabular}{|c|c|c|c|c|}
\hline Canal & Organización & $\begin{array}{l}\text { Temas trata- } \\
\text { dos }\end{array}$ & $\begin{array}{l}\text { Estética y téc- } \\
\text { nica }\end{array}$ & $\begin{array}{l}\text { Perfil, siner- } \\
\text { gias otros }\end{array}$ \\
\hline Korah & $\begin{array}{l}\text { Algo más de } 250 \\
\text { vídeos, muchos } \\
\text { de ellos organiza- } \\
\text { dos en listas de } \\
\text { reproducción. } \\
\text { Publica con relati- } \\
\text { va periodicidad. }\end{array}$ & $\begin{array}{l}\text { Doblajes de } \\
\text { vídeos virales } \\
\text { breves de Inter- } \\
\text { net (“Doblando } \\
\text { Virales"), parodias } \\
\text { de personajes } \\
\text { famosos, anun- } \\
\text { cios de teletienda, } \\
\text { programas de TV, } \\
\text { videojuegos, etc., } \\
\text { además de video- } \\
\text { blogs. }\end{array}$ & $\begin{array}{l}\text { Calidad de ima- } \\
\text { gen no muy alta } \\
\text { (influida por los } \\
\text { vídeos originales } \\
\text { utilizados). } \\
\text { Audio impecable, } \\
\text { con un doblaje } \\
\text { a medio camino } \\
\text { entre la parodia } \\
\text { castiza y la locu- } \\
\text { ción deportiva, } \\
\text { según el caso. }\end{array}$ & $\begin{array}{l}\text { Es actor de dobla- } \\
\text { je y locutor, tanto } \\
\text { en cine como } \\
\text { series, anuncios } \\
\text { publicitarios o } \\
\text { videojuegos. } \\
\text { También dirige y } \\
\text { presenta su pro- } \\
\text { pio programa de } \\
\text { radio. }\end{array}$ \\
\hline Keunam & $\begin{array}{l}\text { Unos } 210 \text { vídeos, } \\
\text { muchos de ellos } \\
\text { recopilados en } \\
\text { listas de repro- } \\
\text { ducción, especial- } \\
\text { mente las series } \\
\text { de “Disney Ibéri- } \\
\text { co”. } \\
\text { Publica de forma } \\
\text { irregular, pudien- } \\
\text { do pasar meses } \\
\text { sin subir nuevo } \\
\text { contenido. }\end{array}$ & $\begin{array}{l}\text { Doblajes castizos } \\
\text { de los Clásicos } \\
\text { Disney (“Disney } \\
\text { Ibérico”), parodias } \\
\text { musicales, aparte } \\
\text { de otros doblajes } \\
\text { paródicos de cine } \\
\text { o series, vídeos de } \\
\text { imitaciones, etc. }\end{array}$ & $\begin{array}{l}\text { Correcta calidad } \\
\text { técnica. Doblajes } \\
\text { divertidos e inte- } \\
\text { resantes, imitan- } \\
\text { do voces. } \\
\text { Uso de música } \\
\text { acorde al contex- } \\
\text { to cómico. }\end{array}$ & $\begin{array}{l}\text { Actor de dobla- } \\
\text { je profesional } \\
\text { de cine y series. } \\
\text { Participante en } \\
\text { programas de TV } \\
\text { como “Got Talent } \\
\text { España" o “Tu } \\
\text { cara no me suena } \\
\text { todavía”. } \\
\text { Ha realizado } \\
\text { diversas colabora- } \\
\text { ciones con otros } \\
\text { youtubers. }\end{array}$ \\
\hline HDub & $\begin{array}{l}\text { Casi } 30 \text { vídeos, la } \\
\text { mayoría organi- } \\
\text { zados en listas de } \\
\text { reproducción. } \\
\text { Prevalece su } \\
\text { canal secundario } \\
\text { Hache, donde } \\
\text { sube vídeos cada } \\
\text { cierto tiempo, } \\
\text { aunque en algu- } \\
\text { nas ocasiones } \\
\text { llega a haber } \\
\text { recesos de varios } \\
\text { meses, debido a } \\
\text { la complejidad de } \\
\text { sus vídeos. }\end{array}$ & $\begin{array}{l}\text { Parodias de } \\
\text { películas y series, } \\
\text { conocido especial- } \\
\text { mente por "Walt } \\
\text { Disney Pichas" } \\
\text { (doblajes paró- } \\
\text { dicos de Clásicos } \\
\text { Disney). } \\
\text { Humor absurdo } \\
\text { plagado de refe- } \\
\text { rencias cinéfilas. }\end{array}$ & $\begin{array}{l}\text { Calidad audiovi- } \\
\text { sual excelente, } \\
\text { tanto en vídeo } \\
\text { como en sonido. } \\
\text { Mezcla múltiples } \\
\text { referencias en sus } \\
\text { vídeos. } \\
\text { Destaca el uso de } \\
\text { efectos visuales } \\
\text { en la postproduc- } \\
\text { ción. } \\
\text { Los doblajes } \\
\text { están realizados } \\
\text { de forma muy } \\
\text { profesional. }\end{array}$ & $\begin{array}{l}\text { Actor de doblaje } \\
\text { profesional de } \\
\text { cine y series, tan- } \\
\text { to en castellano, } \\
\text { como en catalán. } \\
\text { Ha colaborado } \\
\text { con una gran } \\
\text { cantidad de } \\
\text { youtubers en sus } \\
\text { vídeos, e incluso } \\
\text { en otros canales. }\end{array}$ \\
\hline
\end{tabular}

Tras el análisis de los canales, se han observado una serie de características comunes de los autores. Todos fueron pioneros del doblaje paródico en YouTube en España y han sabido crear su estilo propio, basado en la originalidad, creatividad, talento y reflejo de 
sus identidades y personalidades. Precisamente ésos son sus activos y en eso se basa esta investigación: que fueron muy originales al crear este tipo de doblajes paródicos y que han sabido crear estilos únicos muy interesantes. En ocasiones pueden llegar a ser complementarios, lo que ocasiona que su audiencia se cruce. De ahí también las sinergias que se han observado entre los creadores.

Organizan los contenidos de los canales de forma temática, en listas de reproducción. Esto resulta fundamental para sus seguidores, ya que pueden estar pendientes de determinados contenidos, que se convierten casi en sagas, de modo que generan esa necesidad en su audiencia y fomentan la fidelidad de sus receptores.

En relación a la temática, suelen tomar elementos muy reconocibles por el público, como los clásicos de Disney o personajes públicos, y los parodian de forma muy original. Además, los vídeos parodiados suelen ser inicialmente para público infantil o juvenil ("Art Attack" o productos Disney) y son transformados en humor plagado de lenguaje vulgar y malsonante, con recurrentes alusiones sexuales. Se aprecia la importancia de lo "glocal" (Gallardo, 2012): plantear un tema de interés global, pero hacerlo suyo y de interés para la audiencia mediante la inserción de referencias locales.

También se caracterizan por estar pendientes de la actualidad y realizar vídeos muy oportunos en relación a ello. Por ejemplo, si hay un spot publicitario polémico, como el caso del de Loewe de 2012, rápidamente realizan su doblaje paródico versionándolo (cada autor con su estilo particular). Con esto consiguen que un vídeo ajeno, que ya es muy popular, genere en sus doblajes también esa expansión viral. Todo ello se debe a que ofrecen una alternativa cómica al vídeo que inicialmente no tenía ese tono, lo que lo hace más apetecible para la audiencia (algo similar a lo que ocurre con el infoentretenimiento y la información pura; Aguilera, 2019).

Todos han publicado vídeos de doblajes que se han convertido en virales de gran trascendencia y repercusión mediática, como "La Batamanta" (Loulogio), los “Doblando Virales" (Korah), la parodia del anuncio de Loewe (Desahogada), algunos episodios de "Disney Ibérico" (Keunam), o los "Walt Disney Pichas" (HDub), por poner algunos ejemplos. Los éxitos iniciales les dieron a conocer y luego han ido puliendo y mejorando su estilo, de modo que se han convertido en autores de culto para unos seguidores muy motivados y activos.

Otro rasgo común son las colaboraciones entre ellos y con otros autores. Algunos ejemplos serían: Desahogada participando en vídeos de Dulceida o Andrea Compton o, también, Keunam interviniendo en el canal de HDub y viceversa. Son autores que más o menos han coincidido en el tiempo y que compiten, pero también se admiran mutuamente, por lo que les gusta hacer colaboraciones, lo que propicia, además, que sean más conocidos por las audiencias de los otros creadores.

Casi todos han tenido alguna reclamación por cuestiones de derechos (en algún caso fraudulenta), ya que se aprecia que no suelen pedir permiso previo de uso de los originales. Los mecanismos automatizados que ofrece YouTube a los autores para controlar su material protegido (content ID) a veces les ocasionan problemas. Hay que recordar que un doblaje paródico se basa en la elaboración de una creación humorística basada en un original previo (de tono serio). Al no solicitar permiso con antelación, los autores originales y/o distribuidores oficiales a veces les reclaman por su uso. 
En relación a la estética y la técnica, salvo HDub, con unos doblajes de gran calidad técnica en todas sus facetas que le hacen destacar en ese ámbito, los demás se suelen caracterizar por una estética de calidad media, ya sea derivada de los originales, ya sea porque hay una cierta búsqueda intencionada de lo cutre. Hay que aclarar que esto fue así especialmente en los inicios. Con el paso de los años y las opciones en formatos de calidad que ha ido habilitando YouTube, esto ha ido evolucionando a mejores vídeos, ya que el estándar se va perfeccionando y es a lo que el usuario final está acostumbrado.

Los vídeos publicados con los doblajes suelen tener una interacción alta, a veces también en perfiles en otras redes sociales. Como se ha dicho, los seguidores suelen ser muy activos y dejan comentarios a los autores, lo que causa un gran impacto e influencia sobre ellos.

En cuanto a las diferencias existentes, también se pueden destacar algunas. Cada autor tiene su estilo, sus temas y su público específico. La variedad de contenidos y estilos humorísticos les hace distinguirse lo suficiente. Quizás sea probable encontrar a alguien aficionado a HDub, pero no a Loulogio, o alguien seguidor de Desahogada que no lo sea de Korah. Pero sí es más probable encontrar algún fan de Loulogio y Korah al mismo tiempo, o de Keunam y HDub, puesto que son autores que sí pueden tener más rasgos en común a nivel estilístico.

En cuanto a sus perfiles, Loulogio y Desahogada no son profesionales de la locución ni de los medios, si bien la autora sí ha realizado después doblajes profesionales. Mientras que los otros tres creadores sí se dedican a ello profesionalmente. Esto repercute en la calidad técnica de los doblajes y del producto final, ya que están más cuidados, incluyendo todo tipo de efectos de sonido, y separando de forma detallada las pistas de audio para su posterior doblaje y posproducción. Sin embargo, Loulogio es el que menos cuida el sonido a nivel técnico y elabora unas locuciones de menor calidad (no se sabe con seguridad si por la falta de formación y profesionalidad o porque busca una menor calidad con finalidad humorística).

La cantidad de voces que incluyen en sus vídeos es diferente. Loulogio y Korah suelen ser exclusivamente ellos mismos quienes doblan las voces de sus vídeos, mientras que Keunam y HDub cuentan asiduamente con colaboradores, especialmente HDub, con una cantera fija de compañeros. Desahogada, por su parte, suele realizar las voces ella misma casi siempre, pero contando con colaboraciones en momentos puntuales.

Al igual que varía la calidad del audio, también sucede lo mismo con la imagen y con la postproducción en general. Loulogio y HDub serían los dos extremos: el primero de ellos trabaja con vídeos en menor resolución y unos efectos más pobres, mientras que el segundo publica sus vídeos en alta definición y con todo tipo de trucos técnicos en cuanto a efectos visuales y montaje en general, como resultado de muchas horas de dedicación. En la actualidad, Desahogada, Korah y Keunam también suelen trabajar y publicar vídeos en una buena calidad de imagen.

Los guiones no siguen las mismas pautas. Mientras que algunos como HDub planifican minuciosamente lo que van a doblar, y que se corresponde con el proceso habitual, hay otros como Keunam que reconocen una cierta improvisación a la hora de locutar.

La constancia con sus canales es muy diferente. Por lo general, ninguno de ellos sube vídeos de forma masiva en poco tiempo puesto que requieren mucha planificación. No 
obstante, algunos como Loulogio lo hacen de forma periódica y otros como Keunam son bastante irregulares.

Loulogio o Keunam expanden sus facetas de showman en los escenarios (con monólogos e imitaciones/canciones, respectivamente). Korah y HDub también acuden a algunos eventos, pero con un tono diferente, más relacionado con su labor en YouTube o con el doblaje profesional. Por su parte, Desahogada se mantiene en el anonimato, sin exposición pública (aunque participa de forma puntual en algunas campañas con marcas).

\section{Conclusiones}

La principal contribución que se proponía desde esta investigación era el objetivo general del mismo, analizar algunos de los canales de doblaje más representativos en YouTube, en España.

En relación a los objetivos específicos, en esta investigación se ha explorado la plataforma y se ha seleccionado una muestra de cinco canales que han sido analizados de forma exhaustiva. Tras dicho análisis, se han establecido sus principales características (expuestas en el epígrafe anterior), que se pueden considerar definitorias de este tipo de doblajes paródicos. Estas características ayudan a comprender este fenómeno de éxito en España y otros países, como, por ejemplo, EE.UU. (Boxman-Shabtai, 2019), en especial en la última década.

YouTube inició un fenómeno sin precedentes, revolucionando la interdimensionalidad del panorama audiovisual, y consiguiendo una expansión global que nunca habían conseguido otros medios tradicionales, lo cual sólo es entendible dentro de un contexto donde Internet es el foco de gran parte de nuestra vida diaria en la actualidad.

A través de conceptos como "democratización", "DIY", o "desintermediación" se pone de manifiesto el reflejo de una sociedad que, con el paso de los años, y sobre todo desde comienzo del siglo XXI, ha ido migrando al entorno online, adaptándose a este nuevo mundo virtual, e incorporando algunas de estas herramientas para sacar provecho de un modo personal y profesional, pudiendo suponer una oportunidad de negocio.

Los doblajes paródicos dentro de este entorno web se amoldan a la plataforma YouTube para ofrecer contenido original, potencialmente viral porque está enfocado al gran público, sin tener que recurrir a grandes medios como la televisión. Los doblajes analizados, apropiándose de elementos "glocales", encuentran el punto exacto de comicidad para agradar a un gran abanico de espectadores, aunque mayormente afincados en España. También se basan en la influencia de experiencias televisivas previas como los doblajes de "El informal", puesto que el público entiende este formato y es afín a él.

Los youtubers estudiados son creadores que han sabido aprovechar el impulso de Internet, de modo que utilizan YouTube como un escaparate para mostrar al mundo este tipo de creaciones audiovisuales que, de otro modo (o en otros tiempos), no hubiesen tenido posibilidad de difundir. Se observa que, aunque cada uno de ellos pueda tener aspiraciones diferentes, pues no todos tienen la misma constancia, ni dedicación, ni siquiera la misma calidad, sí tienen todos unas pautas comunes que han sido descritas, respondiendo así a las preguntas de investigación iniciales. 
Mediante el análisis exhaustivo de los canales de los autores, se ha podido observar una cierta evolución en los mismos, no sólo tecnológica como consecuencia de la mejora de la plataforma, sino también por la mejora de las herramientas (smartphones, micrófonos, etc.) y técnicas utilizadas por los creadores. Además, la profesionalización de YouTube, como medio generador de ingresos, lo convierte en una plataforma potenciadora del arte audiovisual, financiando los contenidos que poseen una gran cantidad de visitas, para que ese tipo de contenido pueda seguir siendo producido y explotado.

En definitiva, las claves del éxito de estos canales de doblaje paródico se podrían resumir en su originalidad, creatividad, capacidad de comunicación y sentido del humor único; la inclusión de contenidos actuales y virales, con referencias locales y globales, identificables por el público; su buena calidad audiovisual, tanto de locuciones como de postproducción; y que los autores han sabido adaptarse al medio, manteniendo la interacción con seguidores y ofreciéndoles el contenido que demandan, tanto en YouTube como en otros perfiles de otras redes sociales.

\section{REFERENCIAS}

Abad Villamor, A.I. y Fernández Romero, C. (2018). Inmigrantes en las series de televisión Aída y La que se avecina. Entre la parodia y los prejuicios. Ámbitos. Revista Internacional de Comunicación, 40. DOI: https://doi.org/10.12795/ambitos.2018.i40.16

Aguilera García, I.C. (2019). La cultura del humor televisivo: el infoentretenimiento español desde su utilidad para las audiencias, Zer, 25(47), pp. 31-50. DOI: https://doi. org/10.1387/zer.20705.

Andacht (2017). "Tiranos Temblad": Signos paródicos para una comunidad latinoamericana imaginada. DeSignis: Publicación de la Federación Latinoamericana de Semiótica (FELS), No 26, pp. 151-160. Disponible en: http://www.designisfels.net/ publicaciones/revistas/26.pdf [Consulta: 22 de abril de 2020]

Boxman-Shabtai, L. (2019). The practice of parodying: YouTube as a hybrid field of cultural production. Media Culture \& Society, 41 (1), pp. 3-20. DOI: https://doi/ abs/10.1177/0163443718772180

Casares, J. (1961). El humorismo y otros ensayos. Obras Completas, Tomo VI. Madrid, Espasa-Calpe, pp. 21-48. En Valbuena F. y Aladro E. (2002). La comunicación del humor. Cuadernos de Información y Comunicación, 7, pp. 169-187. Disponible en: https://revistas.ucm.es/index.php/CIYC/article/view/CIYC0202110169A [Consulta: 24 de abril de 2020]

Costa, J. (2013). Como doblar un personaje de animación... y no morir en el intento. Fotogramas, $N^{\circ}$ 2037, pp. 102-105. Disponible en: https://www.fotogramas.es/noticiascine/a513084/como-doblar-un-personaje-de-animacion-y-no-morir-en-el-intento/ [Consulta: 14 de mayo de 2020]

Elío, J. (24 julio 2017). "El canal de Korah: el youtuber que te encantará si eres fan de Joaquín Reyes", en El Español. Disponible en: https://www.elespanol.com/ social/20170724/233726958_0.html [Consulta: 5 de febrero de 2020]

Fernández Jiménez, E. (2018). “Las imitaciones humorísticas televisivas en España: 
propuesta de clasificación", en Signa: Revista de la Asociación Española de Semiótica, 27, pp. 293-322. DOI: https://doi.org/10.5944/signa.vol27.2018.19017

Feroz Khan, G. y Vong, S. (2014), Virality over YouTube: an empirical analysis, Internet Research, 24(5), pp. 629-647. DOI: https://doi.org/10.1108/IntR-05-2013-0085

Galindo, F. y Nó, J. (2010). “Evolución de la tecnología audiovisual digital: de la handycam a la estereoscopia, de la tarjeta capturadora al montaje en web 2.0. y de la cinta a YouTube", en Zer, 15 (29), pp. 137-156. Disponible en: https://www.ehu.eus/ojs/index. php/Zer/article/view/1646 [Consulta: 9 de enero de 2020]

Gallardo, J. (diciembre, 2012). El perfil del internauta como espectador de contenidos audiovisuales en Internet: caso YouTube España. Ponencia presentada en el IV Congreso Internacional Latina de Comunicación Social de la Universidad de La Laguna. Disponible en: http://www.revistalatinacs.org/12SLCS/2012_actas/019_Gallardo.pdf [Consulta: 14 de enero de 2020]

Gascón Vera, P. (2019). ‘El Informal', el doblajey su programación en “access prime time" como ejes del éxito televisivo de un formato periodístico de humor. Index.Comunicacion, 9(3), pp. 139-163. Disponible en: https://journals.sfu.ca/indexcomunicacion/index. php/indexcomunicacion/article/view/519 [Consulta: 25 de abril de 2020]

Gayá, V. (2015). “Youtuber o bloguero de profesión”, El siglo de Europa, № 1129, pp. $42-43$. Disponible en: http://elsiglodeuropa.es/hemeroteca/2015/1129/1129Tiemposdehoy. pdf [Consulta: 8 de enero de 2020]

Gómez Morales, B.M. (2015). La parodia en la comedia animada estadounidense de prime time. El caso de la sitcom. Zer: Revista de estudios de comunicación, 20 (39), pp. 67-83. DOI: https://doi.org/10.1387/zer.15519

Gómez Morales, B.M. (2020). Televisión crítica o industria de la risa. El caso de la comedia televisiva española (1990-2018). Signa: Revista de la Asociación Española de Semiótica, 29, pp. 467-494. DOI: https://doi.org/10.5944/signa.vol29.2020.23947

Gordillo Álvarez, I. (2015). La comedia televisiva: clichés, gags y estereotipos como base para el 'buen' humor. En: Puebla Martínez, B; Navarro Sierra, N. y Carrillo Pascual, E. (coord.): Ficcionando en el siglo XXI. La ficción televisiva en España. Madrid: Icono14, pp. 79-101.

Hutcheon, L. (2000). A Theory of Parody: The Teachings of Twentieth-century Art Forms. Urbana: University of Illinois Press.

Israel Garzón, E. y Pomares Pastor, R.A. (2019). “Contenidos virales en los informativos de televisión. El caso del profesor Kelly, entre el humor y el estereotipo", en Dígitos: Revista de Comunicación Digital, 5, pp. 184-209. DOI: http://dx.doi.org/10.7203/ rd.v0i5.144

Ivanov Mollov, P. (2006). Problemas teóricos en torno a la parodia. El "apogeo" de la parodia en la poesía española de la época barroca. Tonos digital: Revista de estudios filológicos, 11. Disponible en: https://www.um.es/tonosdigital/znum11/estudios/12parodia.htm [Consulta: 26 de abril de 2020]

Jaraba, G. (2015). YouTuber: Cómo crear vídeos de impacto y triunfar con ellos en Internet. Barcelona: Redbook Ediciones. 
Jaramillo, D. y Suárez, C. (2013). Las voces de la red: la invisible dinámica del "fandoblaje" en América Latina. Comunicación y Ciudadanía, 6, pp. 76-91. Disponible en: https:// revistas.uexternado.edu.co/index.php/comciu/article/view/3411 [Consulta: 25 de abril de 2020]

Jorge, A.; Marôpo, L. y Nunes T. (2018). 'I am not being sponsored to say this': a teen youtuber and her audience negotiate branded content. Observatorio (OBS*), Extra 0, pp. 76-96. DOI: https://doi.org/10.15847/obsOBS0001382

Krippendorf, K. (1990). Metodología de análisis de contenido. Teoría y práctica. Barcelona: Paidós.

Maranhão de Souza-Leão, A. L.; Melo Moura, B.; Correia de Santana, I. R.; da Silva Nunes, W. K. y Rosa Henrique, V. de M. (2019). Fans Make Art: Authoring and Creativity in the Production of Fanvideos. Revista de Negócios, 24(4), pp. 22-36. DOI: http://dx.doi. org/10.7867/1980-4431.2019v24n4p22-36

Márquez I. y Ardèvol, E. (2018). Hegemonía y contrahegemonía en el fenómeno youtuber. Desacatos: Revista de Ciencias Sociales, 56, pp. 34-49. DOI: https://doi. org/10.29340/56.1876

Méndez García de Paredes, E. (2003). Humor y televisión en España. En: Merlo-Morat, P. y Riesgo-Demange, B. (coord.): L' humour hispanique. Lyon: Université Lumière, pp. 149-190.

Méndez García de Paredes, E. (2014). La parodia informativa como frivolización del discurso político. Círculo De Lingüística Aplicada a La Comunicación, 59, pp. 61-91. https://doi.org/10.5209/rev_CLAC.2014.v59.46709

Murolo, N.L. (2010). “Post-Zapping: Transmite tú mismo. YouTube como la televisión posmoderna", en Revista Razóny Palabra, 71, Disponible en: http://www.razonypalabra. org.mx/N/N71/VARIA/14\%20MUROLO-REVISADO.pdf [Consulta: 10 de enero de 2020]

Nitrihual, L.A. y Galera, J. (2011). “Romeo y Julieta de Cantinflas: El humor en la cultura de masas", en Arte, Individuo y Sociedad, 23 (2), pp. 97-107. DOI: https://doi.org/10.5209/ rev_ARIS.2011.v23.n2.36257

Olmos, F. (19 junio 2017). “Los doblajes de Hombres, Mujeres y Viceversa que triunfan en Facebook", en La Verdad. Disponible en: http://www.laverdad.es/gente-estilo/ doblajes-hombres-mujeres-20170619100643-nt.html [Consulta: 18 de enero de 2020]

Orihuela, J.L. (2002). "Los nuevos paradigmas de la comunicación", en eCuaderno. Disponible en: https://www.ecuaderno.com/paradigmas [Consulta: 2 de febrero de 2020]

Pérez Pereiro, M. (2007). Modalidades humorísticas na comedia televisiva galega, humor e ideoloxía na fórmula televisiva da comedia de situación. Tesis doctoral. Universidade de Santiago de Compostela. Disponible en: https://minerva.usc.es/xmlui/ handle/10347/2381 [Consulta: 28 de abril de 2020]

Pérez, J.P. y Gómez, F.J. (2010). “Paradigmas de la producción audiovisual en la Web 2.0", en Revista Razón y Palabra, 72. Disponible en: http://www.razonypalabra.org.mx/N/ N72/Varia_72/25_Perez_72.pdf [Consulta: 15 de enero de 2020] 
Ramos-Serrano, M. (2007). "Comunicación viral y creatividad", en Revista Creatividad y Sociedad, 11, pp. 202-226. Disponible en: http://hdl.handle.net/11441/26579 [Consulta: 11 de enero de 2020]

Ríos, I. (2011). El difícil reto del monólogo. Humor en televisión. Academiatv: la revista de la Academia de las Ciencias y las Artes de Televisión, 120, pp. 16-19. Disponible en: http://www.academiatv.es/revista/no-120 [Consulta: 28 de abril de 2020]

Sádaba, I. y Rendueles, C. (2016). "Metodologías de análisis del espacio audiovisual online: Entre la innovación y la ansiedad de la novedad", en Revista de Metodología de Ciencias Sociales, 35, pp. 105-124. DOI: https://doi.org/10.5944/empiria.35.2016.17170

Schneider, J. N. (2016). Parody and the Fair Use Defense. Brooklyn Law Review, 81(4), 1777-1812. Disponible en: https://brooklynworks.brooklaw.edu/blr/vol81/iss4/15/ [Consulta: 22 de abril de 2020]

Statcounter GlobalStats (2020). Social Media Stats Worldwide. Disponible en: https:// gs.statcounter.com/social-media-stats [Consulta: 17 de mayo de 2020]

Tobar Zárate, C. (2014). Permiso para reír: la parodia como limitación al derecho de autor. Revista de Derecho Privado, 52, pp. 1-37. DOI: http://dx.doi.org/10.15425/ redepriv.52.2014.12

Valbuena F. y Aladro E. (2002). La comunicación del humor. Cuadernos de Información y Comunicación, 7 (especial monográfico sobre el humor). Disponible en: https:// revistas.ucm.es/index.php/CIYC/issue/view/CIYC020211 [Consulta: 11 de mayo de 2020]

Wimmer, R.D.; Dominick, J. R. (1996). La investigación científica de los medios de comunicación: una introducción a sus métodos. Barcelona: Bosch.

Yin, R.K. (2014). Case study research: design and methods. Thousand Oaks, Canadá: Sage Publications.

\section{Canales de YouTube de los creadores analizados:}

Desahogada: https://www.youtube.com/user/Desahogada

HDub: https://www.youtube.com/user/hctortm2

Keunam: https://www.youtube.com/user/Keunam

Korah: https://www.youtube.com/user/ElcanaldeKorah

Loulogio: https://www.youtube.com/user/loulogio

\section{Agradecimientos}

Los autores quieren agradecer a los evaluadores anónimos de este trabajo las sugerencias aportadas. Consideramos que han ayudado a mejorar en gran medida el resultado final. 